\title{
Plastic Marine Waste and its Potential for Indonesian Indigenous Communities
}

\author{
Jacob Wood (iD https://orcid.org/0000-0002-3096-5159 \\ Swathi Paturi \\ Prerna Puri \\ Emil Senf Jakobsen \\ Sumanth Shankar \\ Pawel Zejden \\ Simona Azzali (iD https://orcid.org/0000-0003-2483-0781
}

James Cook University Singapore

\begin{abstract}
The management of marine waste is an increasingly complex issue facing the world today. Our study provides an interesting take on the issue of marine waste by examining how Indonesian indigenous communities can deal with plastic marine pollution. While there is an obvious need for mitigating plastic use, for effective legislative policies regulating plastic waste management, and to do more to develop sustainable waste management practices; there are also opportunities for indigenous communities to take an innovative approach by using plastic waste in a manner that drives economic development from both non-market and neoliberal theoretical ideologies. As part of this assessment, alongside Indonesian examples we include examples of plastic re-use by indigenous communities of the Philippines and Australia. Moreover, our study highlights some of the areas in which this is being done in the fields of art and infrastructure development.
\end{abstract}

Keywords: Indigenous people, sovereignty, waste management, circular economy, plastic marine pollution, artistic recycling, tropics

eTropic: electronic journal of studies in the tropics publishes new research from arts, humanities, social sciences and allied fields on the variety and interrelatedness of nature, culture, and society in the tropics. Published by James Cook University, a leading research institution on critical issues facing the worlds' Tropics. Free open access, Scopus, Google Scholar, DOAJ, Crossref, Ulrich's, SHERPA/RoMEO, Pandora, ISSN 1448-2940. Creative Commons CC BY 4.0. Articles are free to download, save and reproduce. Citation: to cite this article include Author(s), title, eTropic, volume, issue, year, pages and DOI: http://dx.doi.org/10.25120/etropic.19.1.2020.3697 


\section{Introduction}

$\mathrm{T}$

he advent and spread of globalization has played an influential role in stimulating the demand for, and production of, plastics. As a consequence, every year, 8 to 12 million metric tons of plastic waste is being dumped into the oceans (Rice, 2018). Ocean currents disperse this waste plastic throughout the world causing significant environmental damage. Because plastic materials take such a long time to break down, the objects are capable of travelling thousands of kilometers across the globe, destroying natural ecosystems (Bakir et al., 2014).

Until recent times, societies around the world have done little to plan for, and manage, plastic waste. In addition, there is no single solution that can be effectively applied everywhere. Many countries are banning single-use plastics and trying to adopt a new, circular economy approach, where plastic products are kept in use for as long as possible before reusing, repairing, remanufacturing and recycling the material to create a closed-loop system. However, these changes are often met with resistance by the community in general, as well as by local governments and businesses (Godfrey, 2019). Plastic waste mismanagement has resulted in significant social, economic and ecological costs in both the developed and developing worlds (Thompson et al., 2009). However, some countries are more prone to the hazards of water plastic waste due to long coastal borders or vast archipelagos - as is the case for Indonesia.

As a country of more than 17,000 islands and about 274 million inhabitants, Indonesia struggles to deal with the large amount of plastic waste it creates, with significant amounts washing up on its own shores. However, it should be noted that both internal and external factors are at play here with failures in national, as well as broader regional waste mismanagement systems contributing to the problem (Le Guern, 2018). As a nation, Indonesia is second behind China as the world's worst marine plastic polluters. These two countries significantly contribute to the high levels of Asian plastic waste, with Lebreton et al. (2017) estimating that across Asia rivers account for $67 \%$ of the 1.15 to 2.41 million tonnes of plastic waste entering the ocean every year. Plastic waste washing up along the coastlines has adverse consequences for the indigenous communities that live there.

Our study adopts an integrative literature review approach to highlight the level of waste that exists in coastal areas of the Indonesian archipelago. It also focuses on social benefits of plastic recycling for indigenous peoples and documents the economic returns that can be created by converting plastic trash into valuable 
commodities by recycling and reusing waste in socio-commercial and artistic ways. Furthermore, our research provides appropriate case studies by analyzing how indigenous communities with broadly similar characteristics and lifestyles to that of Indonesian communities have utilized plastic waste. In particular, inspiration has been drawn from tribal Filipino communities that have taken a lead in developing a national plastic craft movement (McKay, 2017), and the Indigenous communities of tropical North Australia who have created a strong art movement based on marine waste. There are a number of similarities between the Southeast Asian nations of the Philippines and Indonesia, with both being among the top five plastic polluters of the world with poor waste management policies and industrial recycling inaccessible to the majority of the population (McKay, 2017; Mann, 2019; Wood, 2018). In addition to this, both nations are archipelagos whose coastlines are home to millions of rural and indigenous populations who do not have the necessary resources or infrastructure to combat waste washing up on their shores. They also share similar socio-economic problems including a lack of access to educational opportunities and government support services. The Northern-most Indigenous Australian communities also have an extensive coastline that spans Aboriginal lands and the Torres Strait Islands, which form maritime borders - and ancient maritime links - with Indonesia.

From a theoretical perspective, our case study analysis provides evidence to suggest that despite neoliberal market ideology often marginalizing indigenous communities, these communities are attempting to overcome such barriers with practical attempts to develop their own plastic recycling market place, and in doing so, seeking to establish their own sovereign and economic independence (Anderson et al., 2008). The study is organized as follows: below, we detail the methodological approach utilized in the study; we then outline the results from our integrative literature review; this leads to a discussion of practical implications for indigenous populations, as well as examples of successful plastic re-use practices in communities; finally, the paper concludes with recommendations.

\section{Methodological Approach}

For the purpose of this study, an integrative literature review was undertaken to provide a comprehensive analysis on marine plastic waste management and to demonstrate evidence of social benefits of plastic recycling for indigenous populations living in the coastal regions of Indonesia. Our decision to focus on this topic reflects both the importance of effective waste management practices and their implications for indigenous people. An integrative literature review is a specific form of research that seeks to not only categorize information about a particular area of study, but also to create new knowledge about topics reviewed (Torraco, 2005, 2016; Heshmati et al., 
2019; Wood et al., 2020). Furthermore, literature reviews are an effective means of succinctly summarizing and critically analyzing an extant body of literature from a particular field of study (Chermack \& Passmore, 2005).

In order to analyze and generate new knowledge on the issues of plastic waste management, the social benefits of plastic recycling for and by indigenous peoples, as well as the economic viability of artistic forms of recycled new product development, our study draws upon existing research on plastic waste and indigenous communities. Based on these overarching principles, a critical analysis of marine plastic waste management and its unique relationship with indigenous people was performed. Information gathered from this preliminary step was then subjected to further scrutiny with the results of the analysis documented in this study.

Journal articles and scholarly books used in our study were primarily obtained through a university specific search engine (JCU One Search). To this end, the articles used in this study were sourced from initial searches through multiple ProQuest databases, which encompassed 43 subsets of databases (such as ABI/INFORM Collection and Social Science Premium Collection, among others) and other online searches to discover relevant articles. The keywords used had to be pertinent and all-inclusive in order to obtain relevant results. The keywords used in the study included: marine plastic waste, sovereign rights, water rights, indigenous people, artistic recycling, waste management, waste to art, plastic waste to art, indigenous arts, and pollution. This systematic approach ensured that the integrity of a robust literature review was maintained, resulting in the selection of relevant articles.

\section{Results: An Assessment of the Key Issues}

In many countries around the world, the sovereign rights of indigenous populations are being undermined on a continual basis. In some cases, these groups are being forced off their land and having to relocate to areas far removed from their traditional way of life. In an attempt to outlaw such practices, organizations such as the United Nations have passed the United Nations Declaration on the Rights of Indigenous Peoples which seeks to protect these groups (United Nations, 2008). Indonesia voted for the declaration, thus adopting principles to protect its large population of diverse indigenous peoples. A significant decision, given the fact that Indonesia is home to over 1,000 different ethnic and sub-ethnic groups, including the 'masyarakat adat', indigenous peoples (literally, 'customary people'), who make up 50 to 70 million of the total population (AMAN, 2012, p.1). However, as the UN resolution is non-binding, the Indonesian government has not been required to implement any supporting domestic regulation (United Nations, 2007). The current Indonesian president, Joko Widodo, 
has expressed his support to do more to protect indigenous peoples in the future. As part of his 2014 commitment, he pledged to return 12.7 million hectares of forest land to indigenous communities; however, as of 2019 only 1.9 million hectares had been returned (Chandran, 2019).

In the context of water rights, many Indonesian indigenous communities have failed to secure equality. This is despite the UN declaring water a basic resource necessary for the survival of indigenous communities (Parriciatu \& Sindico, 2012). The ruling includes freshwater as well as coastal seas, which is important given the role these areas play in the lives of indigenous peoples in Indonesia. Indigenous people's traditions and belief systems often mean that they regard nature with deep respect, embracing the need to live sustainable lives. That indigenous people's territories form $24 \%$ of the land worldwide, but contain $80 \%$ of the world's biodiversity, stands as a testimonial to their sustainable way of living and the importance of safeguarding indigenous territories (Luoma, 2020). For generations these people have used natural resources from the ocean as well as driftwood, and other elements on land, to generate a living. In the contemporary context, many of these factors still apply; however, with the levels of plastic consumption and concomitant waste still increasing, many indigenous populations have sought to creatively re-use and market these waste products as a means of providing for their families. Despite changes in how indigenous communities develop their local economies, many coastal communities still rely heavily on tourism and fishing as their main source of livelihood. Plastic waste along the coast has negatively affected both the fishing and tourism industries while reducing environmental biodiversity, with the economic costs estimated to be in excess of $\$ 2.5$ trillion USD each year (Beaumont et al., 2019, p.193).

The tourism industry is also a key source of plastic waste for countries in the tropics, including Indonesia. As plastic waste along the coastlines increases, indigenous peoples can play a crucial role in promoting a circular economy by treating plastic waste as a commodity rather than a socio-economic and environmental burden. Research suggests that in recent years indigenous groups have sought to view plastic as an opportunity by using recycled plastic waste in building materials to educate tourists on the importance of recycling through mediums like murals and other public art initiatives (Ruhanen \& Whitford, 2019). Such an approach has given them greater economic freedom and a chance to have some autonomy as to how their lives are being shaped (Gregory, 2015). In other contexts, communities such as the Igorot in the Philippines, Aboriginal and Torres Strait Islander communities in Australia, and the villagers of Bangun in Indonesia, are leading the change by utilizing plastic waste as a pathway to socio-economic independence. In particular, the people of Bangun village are improving their livelihoods and potential income sources by sorting the international commercial plastic waste that is dumped in their village. However, it is 
important to note here that the social benefits experienced by local ethnic and indigenous groups are small compared to the social harm and environmental damage caused by waste plastic. In this regard, the population of Bangun village in East Java still face environmental and health risks even as the villagers survive by effectively managing the vast amounts of plastic waste that are imported to the town (Board, 2019).

A further environmental and health issue of plastics is their ability to break down into smaller microplastics, thus contaminating the surrounding water, air, land and food networks (Board, 2019; Glade-Wright, 2019, pp.71-72). The hazards associated with microplastic pollution call for urgent re-use and recycling programs as preventative measures to plastic contamination. According to a World Economic Forum 2016 report entitled 'The New Plastics Economy', countries are losing $95 \%$ of the economic value tied up with plastic materials, an amount which is worth $\$ 80$ billion- $\$ 120$ billion annually. The report states that despite relatively developed recycling initiatives, currently only $14 \%$ of plastic is being recycled. Even sophisticated and well-developed waste management systems like those in Europe and the United States are unable to prevent some 170,000 tonnes of plastic waste leaking into the world's oceans each year. Given these concerns, the New Plastics Economy report calls for creating an immediate after-use plastic economy with an economic incentive in order to prevent leakage of plastic into natural systems. Moreover, when taking into consideration sorting and reprocessing losses, only $5 \%$ of the plastic is actually recycled. And even if it is recycled, it ends up being recycled for lower value applications that cannot be recycled further. The report also points out that a key reason behind the low recycling rates is the fragmented local collection processes and lack of coordination across the value chain. This is even more relevant for middle income countries in Asia which account for $80 \%$ of the leakage (World Economic Forum, 2016, p.18). While working with local informal and formal waste sectors is essential in preventing leakage of waste into the ocean, a more significant effort that propels the development of 'non-market entrepreneurship' (Shockley et al., 2008) and a circular economy is required (World Economic Forum, 2016). In the case of Indonesia, there is a strong connection between the formal and the informal waste sector, or 'waste pickers' as they are often (derogatively) called. Although the exact number of people working in the informal waste sector is unknown, it is estimated that about 40,000 people were involved in waste collection in Jakarta as far back as 1992 (Sasaki et al., 2014). According to a recent study by Putri et al. (2019), each person involved in the collection of waste in Jakarta recovers some 239 kilograms each month. However, the efficiency and integration of the formal and informal waste sectors in Indonesia is facilitated by a chain of middlemen, and despite positive contributions from the informal waste sector, policy makers maintain an indifferent attitude towards people working in the informal sector (Sembiring \& Nitivattananon, 2010; Putri et al. 2019). Waste management in 
Indonesia is not limited to the amount of domestic waste generated; Indonesia also imports plastic waste. Plastic waste imports stood at a staggering 35,000 tons per month in late 2018 (The Business Times, 2019). Domestic waste, together with imported waste, create challenging circumstances for waste management, resulting in high leakage into coastal areas. Conventional waste management practices in Indonesia, from collection, to disposal in landfills, through sorting, recycling etc, are not highly efficient; this is evidenced by the fact that Indonesia is second only to China as the world's largest contributor to marine waste (Whiting, 2019).

As a result of growing concerns over waste, steps can be taken to utilize plastic waste to address socio-environmental concerns. In Nigeria, a 2015 European Research Council funded project, known as the 'DirtPol', has seen several artists use plastic waste as a primary material in their art works (Wagner-Lawlor, 2018). Furthermore, the study highlighted that of the artists interviewed, many have seen their artworks as a means of recapturing their own indigenous identities that had been threatened in an era of highly dominant multi-national oil firms in Nigeria (Wagner-Lawlor, 2018). As one artist noted, plastic waste art is an opportunity for them to express how the region's identity has been socially, economically and environmentally transformed in recent times (Wagner-Lawlor, 2018). Moreover, the 'plasticization' of local communities in the Lagos region of Nigeria has seen several artists describe their work as a means of managing plastic waste and making it part of their everyday life; in particular, using waste plastics to create everyday objects such as chairs and tables.

In another study, Butler et al. (2013) have shown that Australian Indigenous artists, Indonesian fishermen, and fishing net manufacturers from Korea, are important stakeholders in the value chain assessment of fishing nets. In their assessment, they found that discarded or lost fishing nets by Indonesia fishermen contribute to marine plastic debris and hold socio-environmental and economic costs for the indigenous peoples in both Indonesia and Australia. In an effort to make best of this waste, indigenous local communities are working with Australian Indigenous rangers to pick up the marine debris and convert it into sculptures or artworks. The artists' motives are not only economic; they also seek to raise awareness among other stakeholders. Efforts in this regard include: Korean fishing net manufacturers in an effort to have them use better materials; fishery management institutions in Indonesia to reduce fishing net loss; as well as alerting general consumers of fish products to the growing magnitude of the problem (Butler et al., 2013).

Other studies highlighted the growing number of designers in Southeast Asia that are using a set of open-source, easy-to-build tools to recycle plastic and manufacture new plastic products on their own (Peters, 2017). Plastic waste can act as a driver of economic development for indigenous populations. In this sense, forms of non-market 
entrepreneurship have been used by indigenous communities to sell their products. The Indonesian Government has estimated that recycled plastic exports could be worth $\$ 441$ million in 2019 (Reuters, 2019). However, it is imperative that governments are mindful of the need to look at more long-term solutions for efficient wastemanagement practices. To do so, the focus needs to be on the development of a circular economy model where waste is re-inserted back into the supply chain to improve business sustainability (Luiz et al., 2018). Government driven initiatives that provide indigenous peoples with both the skills and technologies would also greatly assist them in terms of reclamation of their water rights. The private sector also plays an important role in improving outcomes for indigenous populations, with research showing that firms specializing in environmental sustainability are best placed to do so (Romero-Hernández \& Romero, 2018).

In addition to concerns regarding waste management practices is the issue of global pollution. With both factors closely related, their potential impacts on indigenous populations is significant. Inadequate waste mismanagement practices add to mass pollution of water, air and soil ecosystems. Although some countries manage their plastic waste more efficiently than others (Guerrero et al., 2013), developing economies such as China, Indonesia, the Philippines, Vietnam and Sri Lanka contribute around $55 \%$ of the global marine plastic pollution (Rhodes, 2018). In addition to a country's economic development level, population growth, cultural habits, literacy rates, and the efficacy of local infrastructure to retain waste, are also important contributing factors to the way in which waste is managed (Boucher \& Billard, 2019). While the exact amount of plastic waste is unknown (Jambeck et al., 2015), mismanaged waste plastic from industrial activities and inappropriate dumping and disposal has had a significant impact on indigenous populations. Worldwide, fishermen, such as local subsistence fishermen in Indonesia (Nash, 1992), have seen their fishing instruments destroyed by plastic debris requiring them to change fishing areas and use different types of gear, sometimes against economic interests. Since the vast majority of plastics are non-degradable, finding a long-term sustainable alternative should be a global priority.

\section{Discussion}

\section{Artistic Recycling of Plastic Waste}

Global plastic consumption is on the rise, creating additional waste management concerns. The debris deposited along coastlines is having adverse socio-economic and environmental effects on indigenous communities in the tropics. As such, communities need to find alternative ways of managing this marine waste. In a 
response to waste issues, communities around the world are transforming 'debris' into useful items of economic value through artistic practices.

The Igorot people of the Philippines have been proactive in their use of waste to create artistic works. Using waste plastics, the community has been producing backpacks, known as 'Pasiking'. Such moves have replaced the use of traditional materials such as rattan and bamboo in the production of the bags, along with other traditional animal hides which have become rare due to commercial dealers and the exports of arts made from such products (McKay \& Perez, 2017). It should be noted that the collecting and reuse of plastics in the Igorot mountain areas directly impacts coastal communities, as rivers are major carriers of plastics to the sea.

Other Filipino communities have also been participating in the 'plastic craft movement' in an effort to combat plastic waste. The notion of reusing waste is deeply rooted within Filipino indigenous practices such as 'ayyew'. Ayyew is the concept of reusing and recycling all types of waste (Minority Rights Group International, n.d). This customary practice has led to the use of plastic in indigenous Filipino crafts. In and around the Northern Luzon area of the Philippines, indigenous artisans use plastic as a material for their crafts. Although the crafts made from plastic are considered to be fake by dealers, these crafts represent a means of developing indigenous communities (Drazin \& Kuchler, 2015). This, in turn, highlights non-market entrepreneurship.

Indigenous communities of tropical Northern Australia have been making art as a way to deal with marine debris that has washed up on their shores. Utilizing plastic bottles and fish netting retrieved along the coastline, they weave this debris into large fish and coral-like sculptures. For example, the 'Ghost-net Art project' helps to convert discarded 'ghost nets', in other words, discarded or lost large fishing nets, into craft works (Phillips, 2017). The artists working on the ghost net project were not only motivated by economic benefits, but also by social benefits such as collaboration with other people, including artists, rangers and fishermen (Phillips, 2017; Le Roux, 2016a). These 'ghost nets', in the hands of indigenous communities on the west coast of Cape York and in the Torres Strait of Australia, have become story making tools. These communities have testified to the strong creative potential of such nets and their ability to be utilized by artists, who were already aware of the destructive effects of ghost nets on the marine environment (Le Roux, 2016b).

With similar waste washing up on Indonesian shores, Indonesian indigenous populations are well placed to utilize these forms of marine pollution in similar ways. For example, an initiative is set to be launched in Sorake, in which the indigenous Nias people would work with others to establish a business that collects and recycles plastic waste into products that can be sold to tourists (Hakkens, 2018). These examples of 
indigenous community involvement in the marketplace support the belief that they are using plastic as a means of engaging in modern neoliberal markets as a means of driving economic prosperity for their people.

\section{Plastic Waste as Building Material}

While plastic waste is used to create pieces of contemporary art, it can also be used to improve infrastructure for indigenous populations. Indonesia is making progress in this regard, having partnered with Dow Company in 2017 (Bendix, 2019). This partnership has seen the creation of so called 'plastic roads' in many cities including Bali, and Jakarta, while similar projects have been initiated in other parts of the world such as India, the USA and the UK. In Indonesia, these plastic roads, which incorporate melted plastic into road tar, are promoted as a novel waste-disposal method that also produces cheaper and more durable roads than those using conventional materials. While being utilized on major road networks around key cities there are also obvious opportunities for the same production processes to be used in rural indigenous communities in Indonesia. For example, in rural India, 34,000 km of roads have been built using shredded plastic waste because of its unusually strong resistance to high temperatures and cheaper cost than conventional materials (Wood, 2018). With the help and provision of relevant equipment and skills by the Indonesian Government, local indigenous communities could replicate these practices by converting plastic waste to usable construction materials. However, critics argue that plastic roads contain microplastics that are invisible to the human eye and have hazardous health impacts (Leahy, 2019). Moreover, Eriksen et al. (2018) also note that while plastic recycling is highlighted as being a crucial means of economic development for many communities around the world, plastic can be contaminated during use and subsequent waste management. Consequently, if these substances and contaminants are not removed during recycling they may end up going back into river systems, which can create other serious environmental issues.

Plastic waste has also been used by indigenous communities as an important tool in the construction of devises for catching fish. In this instance, plastic water bottles, or alternatively flip-flops, have been used as flotation devices for cultivating seaweed lines. Moreover, large plastic drums have been used as floats for Bagan fishing platforms, a system that was originally developed by the Bugis and Makassarese fishermen of South Sulawesi, but has now been established throughout the Indonesian archipelago. 


\section{Marine Waste Management}

With waste management systems differing throughout the world, there is no one-sizefits-all solution. Additionally, many developed economies have been exporting their plastic waste to developing countries who often do not have the same levels of infrastructure to process the waste. Fortunately, this trend is slowly changing with countries like China and Malaysia refusing to accept waste imports (Watson, 2019). As countries start to reduce or ban plastic waste imports, there is an opportunity for these countries to start developing their own domestic waste management infrastructure.

However, as a developing nation, Indonesia faces its own unique challenges when it comes to plastic waste management. While many common domestic factors are still to blame, the country's $91,363 \mathrm{~km}$ coastline (Sui et al., 2020) means that it is exposed to plastic waste that is generated in other parts of the South East Asian region (Putri et al., 2018). Indonesia therefore needs to work with neighboring governments to ensure that there is a transnational approach to its management and a coordinated effort to tackle the problem by not only restricting the use of plastics, but by also adopting more effective means of managing plastic disposal. In line with new policies on plastics, the Indonesian Government sought to ban imports of plastic waste from the USA in 2019. However, at the time, rather than sending this plastic waste back to the United States, as it said it would, the Indonesian Government re-exported the waste to India, Thailand, Vietnam, Mexico, the Netherlands, Canada and South Korea (Gokkon, 2019). Despite the concerns that this re-exportation raises, the Indonesian Government has taken other proactive measures, such as placing a ban on the use of plastic bags from supermarkets; a measure which began in early July 2020. As part of the new regulation, shopkeepers must provide environmentally-friendly carry bags or else face penalties that range from written warnings, to fines of anywhere between $\$ 360$ and $\$ 1,800$, or even the termination of trading permits for retailers (Reuters, 2020).

\section{Indigenous Peoples}

All around the world, indigenous communities have been ignored, mistreated, and marginalized. A clear illustration of this has been their inability to secure land and water rights. Moreover, indigenous communities are frequently evicted from their lands due to the development of hydro-electric, mining, tourism, and fishing projects (Berger, 2019). With over 370 million indigenous people living across more than 90 countries, it is imperative that more is done to recognize these communities' rights (The World Bank, 2019). 
Indonesia faces similar challenges as it is home to numerous and diverse indigenous communities. Despite the significant size of these communities, the Indonesian Government has done little to secure land and protect other sovereign rights of the 'masyarakat adat'. Additionally, laws that support intensive deforestation efforts remain unchanged, as does a lack of infrastructural development in indigenous territories (Jacquelin-Andersen, 2018, p. 295). While Indonesian civil societies support indigenous communities' fight for land ownership and the protection of local traditions, the government has been too slow in implementing meaningful change, despite the promises made in 2014 by the Indonesian president (Perkasa, 2014). Additionally, acts of violence and criminalization against indigenous peoples are still commonplace, as there is little enforcement of laws for protection of their human rights, despite some positive changes being made (Jacquelin-Andersen, 2018, p. 299).

On top of deforestation and legal issues, Indonesia also suffers from poor waste management practices, which also impact indigenous communities. While Indonesia has a large coastal area and population, mismanaged plastic waste has often been left to contaminate these areas and communities. As plastic materials take many decades to decompose - and their decomposition leads to the exacerbated problem of microplastics - this waste has a profound impact on sea-life and the soil. From a global perspective, this, in turn, makes fishing challenging, agricultural practices unstable and access to fresh water limited (Villarrubia-Gómez et al., 2017).

\section{Recommendations and Conclusion}

The indigenous populations of Indonesia have a history of being oppressed and unrecognized; and while they have been slowly granted appropriate rights - lands being one of them (IWGIA, n.d) - they are now facing new challenges, including those posed by plastic waste. As a country with $70 \%$ of the population living in coastal areas (Dahuri, 2020), Indonesia is at greater risk from the adverse consequences that plastic waste brings. Moreover, as indigenous communities often rely on natural ecosystems in order to survive, marine waste is a significant issue. However, in an attempt to combat the threat posed by plastic waste, these communities can shift their perspective from waste plastic as a no-value waste product, to plastic as a reusable commodity that can be harnessed to improve their own socio-economic conditions.

Our examples of the indigenous communities in Australia, and the Philippines, have highlighted the ways in which these communities have sought to recycle plastic waste into objects of economic value such as art works and craft bags. Moreover, our article has suggested that plastic waste has the potential to not only help in improving the economic conditions of communities, but also in addressing problems associated with 
the scarcity of traditional materials, such as in the case of the Igorot community in the Philippines with scarcer access to rattan. Indeed, developing these forms of market entrepreneurship could further benefit and strengthen indigenous communities. Promoting types of entrepreneurship which are not being undertaken solely for purposes of maximizing profit; but also include, for example, social enterprise, nonprofit entrepreneurship, or policy entrepreneurship, could lead to better management of plastic waste. For example, in Australia, indigenous communities have used plastic waste as a means of gaining global awareness regarding their plight. Plastic waste has also been used as a construction material to improve infrastructure and accessibility, with the Indonesian and Indian Governments working with industry to create plastic roads. Assistance can be provided to the indigenous communities to replicate these construction projects from plastic waste.

In order to address the issues surrounding waste management practices and the rights of indigenous peoples, the Indonesian Government should work directly with indigenous communities to provide incentives to recycle plastic and help them establish recycling centers. In a broader sense, the Government should also enact strict laws to reduce the usage of plastic as an immediate measure, thereby minimizing the amount of waste that washes up along coastal areas. While such measures would not be easy to implement, they do represent ways in which the Indonesian Government can demonstrate their serious stance on the issue of plastic waste. Along with sustainable circular economy practices the priority for the Indonesian Government is to harness traditional methods and new technologies that both mitigate plastic use and lead to the creation of new biodegradable materials. 


\section{References}

AMAN (Aliansi Masyarakat Adat Nusantara) (2012, November). Indonesia: Country technical note on indigenous peoples' issues. International Fund for Agricultural Development (IFAD). https://www.ifad.org/en/web/knowledge/publication/asset/40261511

Anderson, R. B., Macaulay, S. W., Kayseas, B., \& Hindle, K. G. (2008). Indigenous Communities, Entrepreneurship, and Economic Development in the New Economy. Non-Market Entrepreneurship: Interdisciplinary Approaches, 89-123. https://doi.org/10.4337/9781848445154.00013

Bakir, A., Rowland, S. J., \& Thompson, R. C. (2014). Enhanced desorption of persistent organic pollutants from microplastics under simulated physiological conditions. Environmental Pollution, 185, 16-23. https://doi.org/10.1016/j.envpol.2013.10.007

Beaumont, N. J., Aanesen, M., Austen, M. C., Börger, T., Clark, J. R., Cole, M., Hooper, T., Lindeque, P.K., Pascoe, C., \& Wyles, K. J. (2019). Global ecological, social and economic impacts of marine plastic. Marine Pollution Bulletin, 142, 189-195. https://doi.org/10.1016/j.marpolbul.2019.03.022

Bendix, A. (2019, March 6). A major chemical company is building roads made of recycled plastic. They've already stopped 220,000 pounds of waste from ending up in landfills. Business Insider. https://www.businessinsider.sg/dow-chemical-recycledplastic-streets-2019-2/?r=USandIR

Berger, D. N. (2019). The Indigenous World 2019. https://www.iwgia.org/en/documents-andpublications/documents/4-the-indigenous-world-2019/file

Board, J. (2019, July 7). The Indonesian village being buried by the developed world's waste. Channel News Asia. https://www.channelnewsasia.com/news/asia/plasticwaste-recycling-indonesia-bangun-environment-11688000

Boucher, J., \& Billard, G. (2019). The challenges of measuring plastic pollution. Field Actions Science Reports, 19, 68-75.

Butler, J., Gunn, R., Berry, H., Wagey, G., Hardesty, B., \& Wilcox, C. (2013). A Value Chain Analysis of ghost nets in the Arafura Sea: Identifying trans-boundary stakeholders, intervention points and livelihood trade-offs. Journal of Environmental Management, 123, 14-25. https://doi.org/10.1016/j.jenvman.2013.03.008

Chandran, R. (2019, June 13). 'Too many' maps slow return of Indonesia's indigenous land. Reuters. https://www.reuters.com/article/us-indonesia-landrights-lawmaking/too-manymaps-slow-return-of-indonesias-indigenous-land-idUSKCN1TE11C

Chermack, T. J., \& Passmore, D. L. (2005). Using journals and databases in research. In R.A. Swanson \& E.F. Holton (Eds.), Research in organizations: Foundations and methods of inquiry (pp. 401-418). Berrett-Koehler.

Dahuri, R. (2020, July 11). Pre-and post-tsunami coastal planning and land-use policies and issues in Indonesia. FAO Website. http://www.fao.org/3/AG124E07.htm

Drazin, A., \& Küchler, S. (2015). The social life of materials: studies in materials and society. Bloomsbury Academic.

Eriksen, M., Pivnenko, K., Olsson, M., \& Astrup, T. (2018). Contamination in plastic recycling: Influence of metals on the quality of reprocessed plastic. Waste Management, 79, 595-606. https://doi.org/10.1016/j.wasman.2018.08.007

Glade-Wright, R. (2019). Plastic Gothic: Frankenstein, Art and the Microplastic Monster. eTropic: Electronic Journal of Studies in the Tropics, 18(2), 68-80. https://doi.org/10.25120/etropic.18.2.2019.3707

Godfrey, L. (2019). Waste Plastic, the Challenge Facing Developing Countries-Ban It, Change It, Collect It? Recycling, 4(1), 3. https://doi.org/10.3390/recycling4010003 
Gokkon, B. (2019, December 10). Indonesia re-exporting illegal waste to other countries, report finds. Mongabay Environmental News.

https://news.mongabay.com/2019/11/indonesia-waste-plastic-export-import-illegal/

Gradín, C. (2015). Race, Ethnicity, Immigration, and Living Conditions in Costa Rica. Review of Income and Wealth, 62(S1), 90-119. https://doi.org/10.1111/roiw.12176

Gregory, P. (2012, April 17). Free Market Solutions to Indigenous Poverty. IPA Review. https://ipa.org.au/ipa-review-articles/free-market-solutions-to-poverty

Guerrero, L. A., Maas, G., \& Hogland, W. (2013). Solid waste management challenges for cities in developing countries. Waste Management, 33(1), 220-232. https://doi.org/10.1016/j.wasman.2012.09.008

Hakkens, D. (2018). Eco tourism: Recycle plastic in Nias. https://davehakkens.nl/community/forums/topic/eco-tourism-recycle-plastic-in-nias/

Heshmati, A., Kim, J., \& Wood, J. (2019). A Survey of Inclusive Growth Policy. Economies, 7(3), 65. https://doi.org/10.3390/economies7030065

IWGIA (n.d). Indigenous Peoples in Philippines. https://www.iwgia.org/en/philippines

IWGIA (n.d). Indigenous Peoples in Indonesia. https://www.iwgia.org/en/indonesia.html Jacquelin-Andersen, P. (2018). The Indigenous World. The International Work Group for Indigenous Affairs. https://www.iwgia.org/images/documents/indigenousworld/indigenous-world-2018.pdf

Jambeck, J. R., Geyer, R., Wilcox, C., Siegler, T. R., Perryman, M., Andrady, A., Narayan, R. \& Law, K. L. (2015). Plastic waste inputs from land into the ocean. Science, 347(6223), 768-771. https://doi.org/10.1126/science.1260352

Leahy, S. (2019, April 15). Microplastics are raining down from the sky. National Geographic. https://www.nationalgeographic.com/environment/2019/04/microplastics-pollution-fallsfrom-air-even-mountains/

Lebreton, L. C. M., Zwet, J. V. D., Damsteeg, J.-W., Slat, B., Andrady, A., \& Reisser, J. (2017). River plastic emissions to the world's oceans. Nature Communications, 8(1). https://doi.org/10.1038/ncomms15611

Le Guern, C. (2009, November 11). When the Mermaids Cry: The Great Plastic Tide. Coastal Care. http://coastalcare.org/2009/11/plastic-pollution/

Le Roux, G. (2016a) L'Art des ghostnets: vingt mille filets autour de la mer / Ghostnet art: twenty thousand nets around the sea. In J. Stéphane, (Ed.) Éditions Arts d'Australie, Paris, France, pp. 9-33.

Le Roux, G. (2016b). Transforming Representations of Marine Pollution. For a New Understanding of the Artistic Qualities and Social Values of Ghost Nets Anthrovision, 4(1). https://doi.org/10.4000/anthrovision.2221

Luoma, C. (2020, May 22). Indigenous Guardianship is Imperative to Protecting Earth's Biodiversity. Minority Rights Group. https://minorityrights.org/2020/05/22/biodiversitydayl

Mann, A. (2019, March 1). The waste challenge: Is Indonesia at a tipping point? The Jakarta Post. https://www.thejakartapost.com/academia/2019/03/01/the-waste-challenge-isindonesia-at-a-tipping-point-1551431355.html.

Mcllgorm, A., Campbell, H. F., \& Rule, M. J. (2011). The economic cost and control of marine debris damage in the Asia-Pacific region. Ocean \& Coastal Management, 54(9), 643-651. https://doi.org/10.1016/j.ocecoaman.2011.05.007

McKay, D. (2017, November 21). These countries are getting creative with plastic waste. World Economic Forum. https://www.weforum.org/agenda/2017/11/heres-the-goodnews-about-plastic-waste.

McKay, D., \& Perez, P. L. (2017). Plastic masculinity: How everyday objects in plastic suggest men could be otherwise. Journal of Material Culture, 23(2), 169-186. https://doi.org/10.1177/1359183517742424 
Minority Rights Group International. (n.d). Minority Stories. http://stories.minorityrights.org/lifeatthemargins/chapter/supporting-indigenouslivelihoods-in-baguio-city/

Nascimento, D. L. M., Alencastro, V., Quelhas, O. L. G., Caiado, R. G. G., Garza-Reyes, J. A., Rocha-Lona, L., \& Tortorella, G. (2019). Exploring Industry 4.0 technologies to enable circular economy practices in a manufacturing context. Journal of Manufacturing Technology Management, 30(3), 607-627. https://doi.org/10.1108/jmtm-03-2018-0071

Nash, A. D. (1992). Impacts of marine debris on subsistence fishermen: An exploratory study. Marine Pollution Bulletin, 24(3), 150-156. https://doi.org/10.1016/0025326x(92)90243-y

Parriciatu, M., \& Sindico, F. (2012). Contours of an Indigenous Peoples' Right to Water in Latin America under International Law. International Human Rights Law Review, 1(2), 211-236. https://doi.org/10.1163/22131035-00102001

Perkasa, V. (2014, September 22). The world conference on indigenous peoples: A view from Indonesia. Council of Councils. https://www.cfr.org/councilofcouncils/globalmemos/world-conference-indigenous-peoples-view-indonesia

Peters, A. (2017, October 30). These DIY Machines Let Anyone Recycle Plastic Into New Products. Fast Company. https://www.fastcompany.com/40486883/these-diymachines-let-anyone-recycle-plastic-into-new-products.

Phillips, C. (2017). Discerning ocean plastics: Activist, scientific, and artistic practices. Environment and Planning A, 49(5), 1146-1162. https://doi.org/10.1177/0308518x16687301

Putri, A. R., Fujimori, T., \& Takaoka, M. (2018). Plastic waste management in Jakarta, Indonesia: Evaluation of material flow and recycling scheme. Springer Professional, 21(4). https://www.springerprofessional.de/en/plastic-waste-management-in-jakartaindonesia-evaluation-of-mate/15859030

Nangoy, F. (2019, August 23). Indonesia's plastic recycling exports hit by tougher rules on imported waste. Reuters. https://www.reuters.com/article/us-indonesiaplastic/indonesias-plastic-recycling-exports-hit-by-tougher-rules-on-imported-wasteidUSKCN1VD1DH.

Diela, T., \& Widianto, S. (2020, January 7). Indonesia's capital bans single-use plastic bags from markets and malls. Reuters. https://www.reuters.com/article/us-indonesiaenvironment-plastic/indonesias-capital-bans-single-use-plastic-bags-from-marketsand-malls-idUSKBN1Z612H.

Rhodes, C. J. (2018). Plastic Pollution and Potential Solutions. Science Progress. 101(3), 207-260.

Rice, D. (2018, September 8). Where did the trash in the Great Pacific Garbage Patch come from? How do we stop it? CNBC. https://www.cnbc.com/2018/09/07/where-did-thetrash-in-the-great-pacific-garbage-patch-come-from.html.

Romero-Hernández, O., \& Romero, S. (2018). Maximizing the value of waste: From waste management to the circular economy. Thunderbird International Business Review, 60(5), 757-764. https://doi.org/10.1002/tie.21968

Ruhanen, L., \& Whitford, M. (2019). Cultural heritage and Indigenous tourism. Journal of Heritage Tourism, 14, 1-13. https://doi.org/10.1080/1743873X.2019.1581788

Sasaki, S., Araki, T., Tambunan, A. H., \& Prasadja, H. (2014). Household income, living and working conditions of dumpsite waste pickers. Resources, Conservation and Recycling, 89, 11-21. https://doi.org/10.1016/j.resconrec.2014.05.006

Sembiring, E., \& Nitivattananon, V. (2010). Sustainable solid waste management toward an inclusive society: Integration of the informal sector. Resources, Conservation and Recycling, 54(11), 802-809. https://doi.org/10.1016/..resconrec.2009.12.010 
Shockley, G.E., Frank, P.M., Stough, R.R. (Eds). (2008). Non-Market Entrepreneurship: Interdisciplinary Approaches. Edward Elgar Pub.

Sui, L., Wang, J., Yang, X. \& Wang, Z. (2020). Spatial-Temporal Characteristics of Coastline Changes in Indonesia from 1990 to 2018. Sustainability. 12, 3242; https://doi.org/10.3390/su12083242

The Business Times. (2019, August 20). Foreign trash 'like treasure' in Indonesia's plastics village. The Business Times. https://www.businesstimes.com.sg/consumer/foreigntrash-like-treasure-in-indonesias-plastics-village

The World Bank. (2019, April 2). Indigenous Peoples. https://www.worldbank.org/en/topic/indigenouspeoples

Thompson, R. C., Swan, S. H., Moore, C. J., \& Yom Saal, F. S. (2009). Our plastic age. Philosophical Transactions of the Royal Society B: Biological Sciences, 364(1526), 1973-1976. https://doi.org/10.1098/rstb.2009.0054

Torraco, R. J. (2005). Writing integrative literature reviews: Guidelines and examples. Human Resource Development Review, 4, 356-367.

Torraco, R. J. (2016). Writing integrative literature reviews: Using the past and present to explore the future. Human Resource Development Review, 15, 404-428.

United Nations (2007). Frequently Asked Questions: Declaration on the Rights of Indigenous Peoples. https://www.un.org/esa/socdev/unpfii/documents/FAQsindigenousdeclaration.pdf

United Nations (2008). United Nations Declaration on the Rights of Indigenous Peoples. Retrieved from https://www.un.org/esa/socdev/unpfii/documents/DRIPS en.pdf

Villarrubia-Gómez, P., Cornell, S. E., \& Fabres, J. (2018). Marine plastic pollution as a planetary boundary threat - The drifting piece in the sustainability puzzle. Marine Policy, 96, 213-220. https://doi.org/10.1016/j.marpol.2017.11.035

Wagner-Lawlor, J. (2018). Poor theory and the art of plastic pollution in Nigeria: relational aesthetics, human ecology, and "good housekeeping". Social Dynamics, 44(2), 198220. https://doi.org/10.1080/02533952.2018.1481685

Watson, I. (2019, April 27). China's recycling ban has sent America's plastic to Malaysia. Now they don't want it. CNN. https://edition.cnn.com/2019/04/26/asia/malaysiaplastic-recycle-intl/index.html

Whiting, K. (2019). Indonesia has a plan to deal with its plastic waste problem. World Economic Forum. https://www.weforum.org/agenda/2019/03/indonesia-has-a-plan-todeal-with-its-plastic-waste-problem/.

Wood, J. (2018, September). Asia's plastic problem is choking the world's oceans. Here's how to fix it. https://www.weforum.org/agenda/2018/09/asia-s-plastic-problem-ischoking-the-world-s-oceans-here-s-how-to-fix-it/.

Wood, J., Park, J., Kim, W. \& Oh, J. (2020). The Relationship between Work Engagement and Work-Life Balance in Organizations: A Review of the Empirical Research. Human Resource Development Review, 19(3), 240-262. https://doi.org/10.1177/1534484320917560

World Economic Forum. (2016). The New Plastics Economy. World Economic Forum. http://www3.weforum.org/docs/WEF The New Plastics Economy.pdf 
Dr Jacob Wood is Associate Dean of Research for the College of Business, Law and Governance, James Cook University, Australia. He is also the Director of the Centre for International Trade and Business in Asia (CITBA) and an Associate Professor of Business at James Cook University Singapore. His research interests are non-tariff barriers, the WTO Dispute Settlement Mechanism and Sustainable Transportation Development. Dr Wood has been published in various outlets including the Journal of Cleaner Production, Sustainability, Scientometrics, Economies, and the Journal of Asia-Pacific Economic Literature among others.

Dr Simona Azzali is a lecturer in urban planning and design at the Singapore campus of James Cook University where she coordinates the Master of Planning and Urban Design and teaches and runs studios on disaster management, urban research methods, planning and sustainable urbanism. She is a member of Lab, and JCU's Centre for International Trade and Business in Asia (CITBA). Dr Simona Azzali is passionate about cities and a strong advocate for a people-oriented and participatory design approaches to build better cities by design.

Swathi Paturi is a CITBA Research Fellow at James Cook University Singapore. She has previously pursued Bachelor's courses in Mechanical Engineering at Waikato University, New Zealand and the University of Cincinnati, USA, where she served as the International Ambassador from 2015-2016. Her research interests include food sustainability, agribusiness, agriculture technology and sustainability.

Prerna Puri, Emil Senf Jakobsen, Pawel Zejden and Sumanth Shankar are MBA students at James Cook University Singapore. 